\title{
Correction to: Field measurements on alluvial watercourses in light of numerical modeling: case studies on the Danube River
}

\author{
Zoltan Horvat • Mirjana Horvat • Dániel Koch • \\ Fruzsina Majer
}

Published online: 26 June 2021

(C) Springer Nature Switzerland AG 2021

\section{Correction to: Environmental monitoring and assessment (2021) 193: 6 https://doi.org/10.1007/s10661- 020-08751-y}

The data collection for the first case study was conducted from the 23rd until the 27th of May in 2011, on the Danube near Mohács in Hungary. should be The data collection for the first case study was conducted from the 23rd until the 27th of May in 2011, on the Danube near Mohács in Hungary (Tamas et al., 2012).

The proposed methodology is based on the simultaneous gathering of all relevant hydraulic, sediment, and constituent parameters. should be The proposed methodology is based on the simultaneous gathering

The original article can be found online at https://doi.org/ 10.1007/s10661-020-08751-y

Z. Horvat $\cdot$ M. Horvat $(\bowtie)$

Faculty of Civil Engineering Subotica, Universityof Novi

Sad, Kozaracka 2a, 24000 Subotica, Serbia

e-mail: isicm@gf.uns.ac.rs

Z. Horvat

e-mail: horvatz@gf.uns.ac.rs

D. Koch · F. Majer

Faculty of Water Sciences, National University of Public

Service, Bajcsy-Zsilinszky street 12-14, 6500 Baja,

Hungary

e-mail: koch.daniel@uni-nke.hu

F. Majer

e-mail: majer.fruzsina.kata@uni-nke.hu of all relevant hydraulic, sediment, and constituent parameters (Tamas et al., 2012).

\section{References}

Tamás, E. A., Varga, A., Sziebert, J., Mátrai, I., Lengyel Varga, A., and Spasojević, M. (2012). Simultaneous bathymetric, flow, sediment and water quality data collection at the Danybe River experimental Mohacs-Bezdan reach, 16th Conference of Serbian Society for Hydraulic Research and Serbian Society for Hydrology, Donji Milanovac, October 22-23, ISBN 978-86-7518-159-0.

Publisher's Note Springer Nature remains neutral with regard to jurisdictional claims in published maps and institutional affiliations. 